\title{
Adjectival Participles Bearing on Unaccusativity Identification. Evidence from Modern Greek
}

\author{
Elisabeth Mela-Athanasopoulou \\ Aristotle University of Thessaloniki \\ ema@enl.auth.gr
}

\section{Abstract}

The adjectival properties of past participles have long been studied in the literature (Levin \& Rappaport 1986, Markantonatou 1995, Embick 2004, Alexiadou 2001, Meltzer-Asscher 2011, et al). The attributive use of past participles will be postulated, in this paper, as an unaccusativity diagnostic for English and Modern Greek (MG). It will be shown that nouns premodified by adjectival past participles can be subjects of unaccusative (yet, not unergative) verbs, e.g. fallen leaves, expired passport, wilted flowers, etc. In MelaAthanasopoulou (2007), I argue that past participles of unaccusative verbs, in MG, turn into adjectives through a morphological rule of conversion. In this paper, I will discuss mismatches (clashes) between predictions of past participle-toadjective conversion and other unaccusativity diagnostics, on the basis of data from MG and English. Whereas the formation of Adjectival Past Participles (APPs) from unaccusative verbs is rather marginal in English, it is quite productive in MG. I will use telicity as a cross-linguistic semantic constraint for the formation of APPs from atelic verbs. Moreover, the distinction between adjectival stative and verbal eventive (resultative) passive participles will also be raised.

\section{The Distinction between Adjectival and Verbal Passives}

As is well known, adjectival passive participles and verbal passive participles are morphologically identical, i.e. they are represented with the same affix, $\{$-ed $\}$ and \{-men-\}, for English and MG. respectively. In 'have' languages (perfective aspect: have en), such as English, however, the phenomenon of APPs is rather marginally productive, especially with unaccusative verbs. Moreover, APPs are closer to passive than to perfect participles. According to Bresnan (1982b), past

(cc) BY-NC-ND 
participles of intransitive verbs convert into adjectivals and appear as modifying past participles, only if their subjects are themes, that is, they undergo the motion or change of state (hence resultative) specified by the verbs they derive from.

Within the GB framework (Chomsky 1981) the APP formation properties are as follows (cited from Levin \& Rappaport, p. 624):

a) affixation of the passive morpheme $\{$-ed $\}$,

b) change of category: $[+\mathrm{V},-\mathrm{N}]$ changes to $[+\mathrm{V},+\mathrm{N}]$

c) Suppression of the external role of the base verb the APP derives from,

d) externalization of an internal role of the base verb,

e) absorption of case, and

f) elimination of the $[N P, V P]$ position.

The main concern here is the identification of the external argument of the base verb the APP premodifies or is predicated of, i.e. the externalization of the internal argument of the base verb. With regard to unergative verbs (e.g. run, swim, cough, cry), subjects are assigned an external argument, namely the thematic role of Agent; whereas with unaccusative verbs (e.g. die, fall, vanish, arrive), subjects lack this active participation. Actually, these surface subjects are non-volitionary passive participants in the action of the verb. The thematic role of agent i.e. external argument is missing with unaccusative verbs. And according to $G B$ theory, such verbs as they fail to assign an external theta role, they also fail to assign accusative case to an object position (Mela-Athanasopoulou, 2007). In $G B$ theory, the surface subject of an unaccusative verb is an object in the deep structure. In other words, an unaccusative verb has an underlying object (which will become the surface subject later in the derivation of the sentence) but no underlving subiect, as in (1) (Mela-Athanasopoulou 2007):

1.

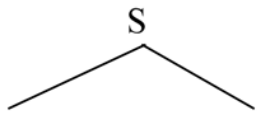

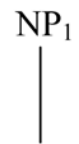

$\varnothing$

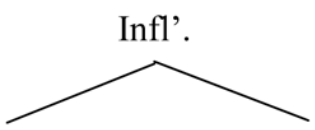

Infl.
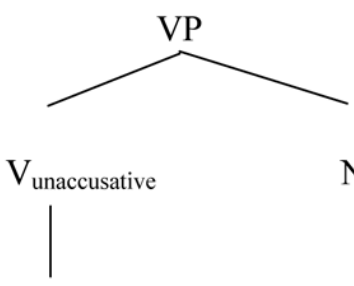

mara $\theta$ ikan

wilted<smiles>CP[NbH2]</smiles>

ta louloudia

the flowers 
Therefore, $\mathrm{NP}_{2}$ ta loulou $\delta \mathrm{ia}_{\mathrm{Nom} / \mathrm{PL} \text {. }}$ will fail to be assigned case ta loulou $\delta \mathrm{ia}_{\mathrm{Accl}}$ pl. unless it moves to a subject position where it will receive nominative case from the Infl. position. On the other hand, with unergative verbs (run, cry, cough, resign, swim, etc.), subjects are assigned an external argument, namely the thematic role of Agent as in (2):

2.

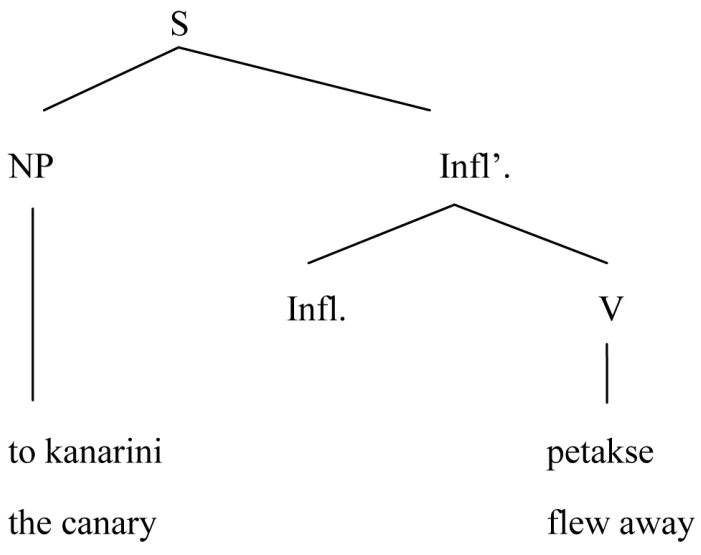

Moreover, the argument of the verbs (verbs of manner of motion) bears the agent role as well as the theme role. Thus, the past participles of ( $3 a-3 f$ ) and (4a4f) are unlikely to occur as adjectivals since they are oriented towards the verb's agent, that is, the subject, which is a volitionary active participant in the action of the verb and it is normally +animate.

\begin{tabular}{|c|c|c|c|}
\hline 3a. & 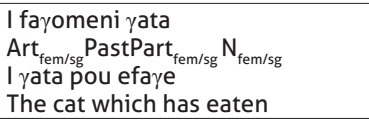 & $4 a$. & $\begin{array}{l}\text { "the eaten cat } \\
\text { The cat that has eaten }\end{array}$ \\
\hline 3b. & $\begin{array}{l}\text { to "chasmourimeno moro } \\
\text { Art }_{\text {ntr/sg }} \text { PastPart } \\
\text { To moro pou chasg } N_{\text {ntr/sg }} \\
\text { The baby who has yawned } \\
\text { The be }\end{array}$ & 4b. & $\begin{array}{l}\text { "the yawned baby } \\
\text { The baby who has yawned }\end{array}$ \\
\hline 3c. & $\begin{array}{l}\text { to *petaymeno kanarini } \\
\text { Art }_{\text {ntr/sg }} \text { PastPart }{ }_{\text {ntr } / \mathrm{sg}} \mathrm{N}_{\text {ntr/sg }} \\
\text { To kanarini pou petakse } \\
\text { The canary that has flown }\end{array}$ & 4C. & $\begin{array}{l}\text { "the flown canary } \\
\text { The canary that has flown }\end{array}$ \\
\hline $3 \mathrm{~d}$. & 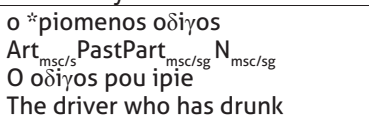 & 4d. & $\begin{array}{l}\text { "the drunk driver } \\
\text { The driver who has drunk } \\
\text { also: the driver who is drunk } \\
\text { (lexicalized) }\end{array}$ \\
\hline 3e. & $\begin{array}{l}\text { O*hyposhemenos politikos } \\
\mathrm{Art}_{\text {msclss }} \text { PastPart } \\
\text { O politicos pou } \mathrm{N}_{\text {msc/sg }} \\
\text { The politician who has promike } \\
\text { The has }\end{array}$ & 4e. & $\begin{array}{l}\text { "the promised politician } \\
\text { The politician who has promised } \\
\text { also: the politician who has been } \\
\text { promised (passive) }\end{array}$ \\
\hline 3f. & $\begin{array}{l}\text { o *treymenos a }{ }^{\text {*litis }} \\
\text { Art }_{\text {msc/sg }} \text { PastPart } \\
\text { O a }{ }_{\text {sc } / \text { sg }} \mathrm{N}_{\text {msc/sg }} \\
\text { The athlete who has run }\end{array}$ & $4 \mathrm{f}$. & $\begin{array}{l}\text { the run athlete } \\
\text { The athlete who has run }\end{array}$ \\
\hline
\end{tabular}


All the English items of (4a-4f) are ill formed as Adjectival Past Participles since none of them derive from unaccusative verbs (hence the unaccusative diagnostic). One can claim that in 'have' languages, such as English, the phenomenon of Adjectival Past Participle formation is non-existent with unergative verbs and little productive with unaccusative ones. Contra Lieber's view (1980) that adjectival past participles are formed from verbal (perfect and passive) participles by affixation of a null adjectival morpheme \{-ed\}, Bresnan (1982) proposed that adjectival participles are closer to passive than to perfect participles. Regarding unaccusative verbs, Markantonatou (1995) argues that past participles of such verbs in MG may convert to adjectives, e.g. pesmenos 'fallen', pethamenos 'dead'. In Bresnan's view then, (3a) i fayomei yata 'the eaten cat', should mean 'the cat was eaten' rather tan 'the cat which has eaten'; hence, the ambiguity of the past participle: either adjectival or verbal ( $4 \mathrm{~d}-$ the drunk driver). Similarly in MG, the items of (3b-3f) are ill-formed as adjectivals. Items (3d-3f) may occur with an ambiguous meaning. Anagnostopoulou (2003), among others (e.g. Levin \& Rappaport 1986) offers some criteria to disambiguate passive participles of any verb \pm transitive, but no mention is done on either unergative or unaccusative verbs, with this respect.

\section{Adjectival Past Participles Bearing on Unaccusativity Definition}

Now returning to the adjectival past participle as an unaccusativity diagnostic, the participles of both MG (3a-3f) and English (4a-4f) data are based on monadic verbs with a single external argument as mentioned earlier in this paper, whereas the adjectival past participles of ( $5 a-5 f)$ are based on monadic verbs with a single internal argument, i.e. they have no underlying subject and fail to assign an external $\theta$-role.

\begin{tabular}{|c|c|c|c|}
\hline 5 a. & $\begin{array}{l}\text { Ta pesmena fila } \\
\text { Art }_{\text {ntr/pl }} A_{\text {ddj }} \text { ntr/pl } N_{\text {ntr/pl }}\end{array}$ & 6a. & The fallen leaves \\
\hline $5 b$. & 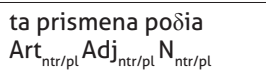 & $6 \mathrm{~b}$. & The swollen feet \\
\hline $5 c$. & 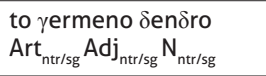 & $6 c$. & "the leant tree \\
\hline $5 d$. & $\begin{array}{l}\text { o kaOismenos papous } \\
\text { Art }_{\text {msc/s }} A_{\text {dj }} \text { ms//sg }_{\text {msc/sg }}\end{array}$ & $6 d$. & "the seated grandfather \\
\hline $5 e$. & 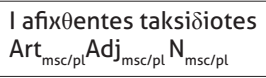 & $6 e$. & "the arrived travelers \\
\hline $5 f$. & $\begin{array}{l}\text { I prokipsases } \delta \text { iskolies } \\
\operatorname{Art}_{\text {fem } / \mathrm{p}} \mathrm{Adj}_{\mathrm{fem} / \mathrm{pl}} \mathrm{N}_{\mathrm{fem} / \mathrm{pl}}\end{array}$ & $6 f$. & "the arisen difficulties \\
\hline
\end{tabular}


From the above picture we can see that there are instances (6c-6f) when a putative unaccusative verb, in English, may not give rise to an adjectival past participle unless it is combined with an adjectival modification of time or manner, e.g. "an appeared novel vs. a recently appeared novel, *a seated grandfather vs. a well seated grandfather, "an emerged problem vs. a newly emerged problem, etc. In other words, in English (but not necessarily in MG) adjectival past participles of unaccusative verbs require obligatory modification. Moreover, one has to take into account the telicity requirement for adjectival past participle formation. Past participles of verbs which are not telic (i.e. do not reach an inherent end-point) cannot be used attributively (6c-6f). Those unaccusative verbs of 'existence' are stative and atelic and, as such, their adjectival past participles cannot be used attributively, e.g. the "existed solution, the "remained documents. In MG, though, adjectival past participles from atelic unaccusative verbs can be used attributively but not predicatively, e.g. ta prokipsanta provlimata 'the emerged problems' vs. *ta provlimata ine prokipsanta 'the problems are emerged', I enapominantes politiki 'the remained politicians' vs. "I politiki ine enapominantes 'the politicians are remained'. On the other hand, telic unaccusative verbs such as melt, freeze, collapse, etc. can yield adjectival past participles which are resultative, e.g. i liomeni sokolata 'the melted chocolate', I soriasmeni skini 'the collapsed tent'. For example, the adjectival past participles, 'melted' and 'collapsed', mean that the chocolate is melted and the tent is collapsed as a result of a melting and collapsing event, respectively (Cleris \& Babiniotis, 1999).

It is not surprising that the acceptability of unmodified adjectival participles of both transitive and intransitive verbs frequently depends on the noun to be premodified as is shown in (7a-b) and (8a-b):

\begin{tabular}{|c|c|c|c|c|}
\hline 7a. & $\begin{array}{l}\text { pliromenos eryatis } \\
\text { "paid worker }\end{array}$ & vs. & 8a. & $\begin{array}{l}\text { pliromenos } \delta \text { olofonos } \\
\text { paid killer }\end{array}$ \\
\hline 7b. &  & Vs. & $8 b$. & $\begin{array}{l}\text { milimenos politicos } \\
\text { spoken to politician }\end{array}$ \\
\hline
\end{tabular}

The informativeness of the adjectival participles of pliromenos and milimenos in (8a-b) (both used attributively and predicatively) is higher than in (7a-b). See Ackerman and Godlberg (1996) for an account for the infelicity of unmodified Adjectival past participles such as those in (7a-b) or forms such as *a combed child vs. a well-combed child, by means of the Non-redundancy constraint (Ackerman \& Goldberg (1996: 21)). 


\section{Conclusion}

In this paper, I have discussed the formation of adjectival past participles in MG as an unaccusativity diagnostic. On the basis of data from MG I have shown that if an adjectival past participle is ill-formed or rejected then the corresponding verb cannot be unaccusative. Moreover, I have raised the issue of telicity as a requirement for Adjectival past participle occurrence and I have shown that adjectival participles cannot be formed from atelic (stative) verbs in English, while they can be marginally formed from such verbs in MG. The whole issue, however, deserves more in-depth research. 


\section{References}

Ackerman, F. and A. Goldberg. 1996. Constraints on Adjectival Past Participles. In A. Goldberg (ed.), Conceptional Structure. Discourse and Language, 17-30. Stanford, CA: CSLI Publications.

Alexiadou, A. 2001. Functional Structure in Nominals: Nominalization and Ergativity. Amsterdam: John Benjamins.

Anagnostopoulou, E. 2003. Participles and Voice. In A. Alexiadou, M. Rathert \& A. von Stechow (eds.), Perfect Explorations. Berlin: Mouton de Gruyter.

Bresnan, J. 1982. The Mental Representation of Grammatical Relations. MIT.

Chomsky, N. 1981. Lectures on Government and Binding. Dordrecht: Foris

Cleris, C. and G. Babiniotis. 1999. Neoelliniki Grammatiki. To rima. (Modern Greek Grammar. The Verb). Athens: Ellinika Grammata.

Embick, D. 2004. On the structure of resultative participles in English. Linguistic Inquiry 35: 335-392.

Levin, B. and M. Rappaport. 1986. The formation of Adjectival Passives. Linguistic Inquiry 17(4): 623-661.

Lieber, R, 1980. The Organization of the Lexicon. PhD dissertation, MIT.

Markantonatou, S. 1995. Modern Greek deverbal nominals: an LMT approach. Journal of Linguistics 31: 267-299.

Mela-Athanasopoulou, E. 2007. Adjectival Participles of Unaccusative verbs. Evidence from Modern Greek. http:icg17.icte.uown.gr/Mela.pdf. 
Major Trends in Theoretical and Applied Linguistics

Meltzer-Asscher, A. 2011. Adjectival passives in Hebrew. Evidence for parallelism between the adjectival and verbal systems. Natural Language \& Linguistic Theory 29: 815-855. 